\title{
The Effects of Design Information on Reliability of Progress and Cost Estimates of Construction Projects: The Case of Two Civil Engineering Projects
}

\author{
Stephen Agyeman ${ }^{1, ~ *}$, Eric Kwaku Asare², Emmanuel Nsiah Ankomah ${ }^{2}$ \\ ${ }^{1}$ Department of Civil Engineering, Sunyani Polytechnic, Sunyani, Ghana \\ ${ }^{2}$ Department of Building Technology, Sunyani Polytechnic, Sunyani, Ghana
}

Email address:

agyengo44@gmail.com (S. Agyeman)

${ }^{*}$ Corresponding author

\section{To cite this article:}

Stephen Agyeman, Eric Kwaku Asare, Emmanuel Nsiah Ankomah. The Effects of Design Information on Reliability of Progress and Cost Estimates of Construction Projects: The Case of Two Civil Engineering Projects. American Journal of Civil Engineering. Vol. 4, No. 6, 2016, pp. 326-336. doi: 10.11648/j.ajce.20160406.19

Received: September 23, 2016; Accepted: October 7, 2016; Published: November 1, 2016

\begin{abstract}
Continuing national disquiet concerning the late completion of road construction projects, high-cost overruns and premature failures of roads partly attributed to inadequate design information is quite worrying. The paper investigated the effects of design information on reliability of progress and cost estimates on two road construction projects in the Brong Ahafo and the Upper East Regions of Ghana. A case study was conducted on the two projects which involved the content analysis of the design documents, interviews with the industry players and personal observations. The study revealed among other things such as lack of design plans before tendering, disparities between design drawing information and Bill of Quantity (BoQ) information, inadequate site investigation and delays in taking decision on variations, affected the smooth progress of these projects. It is recommended that all the stakeholders in the road construction industry treat road design and its related matters with the maximum attention it deserves to curtail the huge avoidable cost the nation is incurring.
\end{abstract}

Keywords: Design Information, Bill of Quantity, Reliability of Progress, Cost Estimates, Construction Projects, Ghana

\section{Introduction}

Construction projects inevitably generate enormous and complex sets of information. The three main parties to a road contract (client, contractor and consultant) form an integral part of the project management team in the construction industry. For the purpose of achieving satisfactory project performance, all the parties meet to take decisions and carry out activities [1]. Effectively managing this bulk information to ensure its availability and accuracy is an important managerial task. Poor or missing information can readily lead to project delays, uneconomical decisions, or even the complete failure of the desired facility [2]. Lack of project knowledge can also lead to project cost overruns and reworks [3]. In both design and construction, numerous operational tasks must be performed with a variety of precedence and other relationships among the different tasks [2].

Design information is very critical in road construction due to the fact that the projects normally span on a very wide geographical settings with different soil and environmental characteristics. It therefore requires detailed feasibility studies to arrive at a comprehensive design information that spells out the conditions at each location and what needed to be done at what point. Carpenter [4], concluded that about $2 / 3$ of project cost overruns can be attributed to design errors and omissions. The problem of inadequate ground investigation has been highlighted by [5] based on an analysis of 10 large highway construction projects, they found that "the final cost was on average $35 \%$ greater than the tendered sum. Half of this increase was directly attributed to inadequate planning or interpretation of ground investigation." Flyvbjerg, Holm and Buhl [6], found that transport projects were susceptible to cost overrun recording actual average cost of $28 \%$ higher than the estimated.

Design information is sometimes inadequate if not missing in most road construction projects in Ghana. According to [7] investigations in the road construction industry from 2003 to 2007 , virtually all road contracts within this period overrun their cost. Projects that are not managed effectively experience countless cost overruns and central to this management process is design information. It is not unusual 
for road contractors to be confronted with unfavorable soil conditions which were never anticipated during the design stage of the project. Thus, resulting in changes in the initial design to accommodate the difficulties encountered thereby delaying or increasing the cost of such project. The average cost overrun after analyzing 10 projects in Ghana was found to be $34 \%$ in 2008 according to [8]. Out of these contracts, 3 overrun their cost more than $15 \%$. The average time delay exceeded a year (thus, around 13.2 months) [8].

It is not also uncommon to see premature failures in portions of recently constructed roads partly because the subgrade strength was overestimated. Thus, situation on the ground was never envisaged neither by the designers of the road nor the contractors. This leads to the Government sourcing for additional funds to fix the problem. Therefore, this article investigated the effects that design information have on reliability of progress and cost estimates of two road construction projects in the Upper East and the Brong Ahafo Regions of Ghana. How to pay attention to design information in order to reduce waste and maximize value in road construction was also looked at. Inadequate design information flow in the road construction process in Ghana has sometimes been associated with delays or design changes. This brings huge cost and budgetary constraints depending on the extent of delays or variations that may occur.

\section{Implications of Design Information}

\subsection{Design Management}

Design management is mostly about managing people, innovation and creativity, functionality, requirements, and constraints. Another vital part of design is the information to communicate the design from the perspective of managing information to achieve information flow [9]. "Design can also be conceived as pairs of supplier-customer. Poor specification of a supplier's work in relation to an internal customer's needs leads to added effort in the customer's activity, and also possibly to rework or continued work in the supplier's activity" [10].

In the project life cycle, the most influential factors affecting the outcome of the project often reside at the early stages. At this point, decisions should be based on competent economic evaluation with due consideration for adequate financing, the prevalent social and regulatory environment, and technological considerations. Architects and engineers might specialize in planning, in construction field management, or in operation, but as project managers, they must have some familiarity with all such aspects in order to understand properly their roles and be able to make competent decisions [11,2].

Hendrickson and $\mathrm{Au}$ [2], outlined several characteristics as being unique to the planning of constructed facilities and should be kept in mind even at the very early stage of the project life cycle. They include the following:

- Nearly every facility is custom designed and constructed, and often requires a long time to complete.

- Both the design and construction of a facility must satisfy the conditions peculiar to a specific site.
- Because each project is site specific, its execution is influenced by natural, social and other locational conditions such as weather, labor supply, local building codes etc.

- Since the service life of a facility is long, the anticipation of future requirements is inherently difficult.

- Because of technological complexity and market demands, changes in design plans during construction are not uncommon.

Best and Valence [12], contended that, the challenge of construction projects often taking longer and costing more than initially projected is often due to poor planning at the pre-design phase of the procurement process. Long et al. [13] also, mentioned that performance problems arise in large construction projects owing to many reasons for instance: incompetent designers or contractors, poor estimation and change management, social and technological issues, site related issues and improper techniques and tools. This confirms the point that designers and contractors have major roles to play in achieving a successful project performance.

\subsection{Delays and Cost Overrun Due to Design Information}

Flyvbjerg [14] focused on mega-projects with contract values in excess of US $\$ 1$ billion, concluded that average cost overruns for civil projects usually about $20.4 \%$ for roads, $33.8 \%$ for bridges and tunnels, and $44.7 \%$ for rail. On the contrary, Love et al. [15] focus was on smaller-projects with average contract value of $A \$ 33$ million reported significantly lower levels of average cost overruns, with roads $13 \%$, and bridges $5.5 \%$. This observed disparity can be expounded by the monetary value of projects. Flyvbjerg, Garbuio and Lovallo [16] and Love et al. [15] have pointed out that transport infrastructure project overruns result from strategic misrepresentation, optimum bias and pathogen errors. Iimi [17] has observed that 9 out of 10 transport projects suffered cost overruns with average cost growth during projects execution being $27.6 \%$. Africa in particular, road contract costs exceeded engineering estimates by $20 \%$ and average delays reached 10 months. Additional $20 \%$ would usually be added during implementation and that construction costs normally increased by $4.6 \%$ per year of delay.

Chan and Kumaraswamy [18] remarked that, project performance measurement include time, budget, safety, quality and overall client satisfaction. This was confirmed by [19] when he stated that project performance measurement means an improvement of cost, schedule, and quality for design and construction stages. This is also in line with [13] assertion that a project performance measurement is related to many indicators such as time, budget, quality, specifications and stakeholders' satisfaction. Chan and Kumaraswamy [20] found poor site management, unforeseen ground conditions and low speed of decision making involved in all project teams as the most significant factors causing delays and problems of time performance in local building works. Okuwoga [21] also identified cost and time performance as the general problems in the construction industry worldwide. According to the [22] in Tanzania, a huge part of the increasing costs in road constructions related 
to miscalculation of some kind already in the design stage. This in turn could for instance be linked to insufficient preparation (ground work) when the design was done or by less effective quality control. The report also emphasized that inadequate design which resulted into change of scope of work during the construction stage is a common cause to cost overrun, according to both consultants and contractors. It was furthermore reported that, frequent failures to pay the contractors on time, resulted in interest payments and failure to process contractors' claims or inspect and approve the completed works of the contractors resulted in cost growth.

Creedy [23], identified the dominant variables that caused cost overruns as frequent design changes (mean $=4.39$ ), fraudulent practices and kickbacks (mean $=4.30)$ and additional works (mean $=4.25$ ). In order to eliminate additional costs associated with design changes and additional works, it is important that careful consideration be given to issues in the preliminary stages, such as site and environmental conditions, design specifications, methods of construction and the availability of labor [23].

\subsection{Consideration of Project Time}

Morledge, Bassett and Sharif [24] reported on data collected in relation to 215 completed projects of commercial and industrial nature and found that $136(63 \%)$ were delivered late. It was concluded that the lateness was mainly due to unrealistic expectation of clients about the project duration during the pre-construction stage.

Government is mostly one main client in the construction industry. The government takes decisions under economic and political considerations. Such considerations may come with directives specifying time periods within which completion of projects are expected. In their bid to comply, members of the project team may be trying to accomplish an unrealistic task. Such situations reflect what [25] learnt in their investigations into determinants of construction duration. They concluded that the overall timescales of many projects appeared to be established as a consequence of commercial or political considerations. They argued that subsequent planning and programming methodologies are then designed to meet these time targets, rather than any objective assessment of durations. Contractors are therefore made to face increased pressure.

Ward, Curtis and Chapman [26], in addition identified that client time expectations are frequently based upon either their own experience of similar works or on advice from "specialist advisors". This behavior of clients may be an indication of the adherence to or rejection of advice of project consultants, who have been formally employed to lead management of building or road projects. In situations where project consultants, considered to be project management experts, play the major role in the establishment of construction time, the effect on project performance may be different. The actions of all parties are therefore important to the project performance.

\subsection{Consideration of Project Cost}

According to [27], project cost is defined as the degree to which the general conditions promote the completion of a project within the estimated budget. It covers total costs incurred from project inception to completion. This definition brings to mind the significance that has to be given to every project management activity carried out through every stage of the project development up to completion. Chan and Chan [28], also argued that, cost is not only limited to the tender sum and that it is the complete cost that a project incurs from inception to completion, which includes any cost arising from variations and modifications during construction period. These cost variables give indication of certain added practices that when engaged in during the project management process would have both direct and indirect implications for the project cost performance. The number and manner in which variation orders are issued by consultants during construction is an important practice to study.

\subsection{Dimensions of Project Success}

There have been different dimensions of measuring project success by different researchers. Sadeh, Dvir and Shenhar [29] measured project success based on the following five dimensions: meeting design goals, benefit to end users, benefit to the developing organization, benefit to the defense and national infrastructure, and overall success (a combined measure for project success). Chan and Chan [28] established eight project success dimensions which include: cost, environmental performance, quality, user expectation or satisfaction, time, commercial or profitable value, health and safety, and participants' satisfaction. Shenhar, Levy and Dvir [30] also divided project success into four dimensions: project efficiency, impact on customer, business success and preparing for the future. The above indicators were used to derive the three basic objectives of construction projects: time, cost and quality [31]. These objectives are the adopted dimensions for measurement of project performance. Measuring the success based on these objectives is considered to yield effective results since project participants are more familiar with the three basic project objectives [1].

\subsection{Current Research Developments}

For the past three years there have been countless research into cost overruns, cost escalations and cost growth resulting in rework of construction and engineering projects. Olaniran et al. [32] for example, stated that up-to-date report showed that $64 \%$ of ongoing megaprojects globally are facing cost overruns. Some researchers have declared as saturated research publications in this area while others are of the view that researchers should rather focus on developing probability theories for rework causation and not causation factors because so called "newly found causation factors of reworks" are duplication of findings decades ago [33, 32, 32]. Some have even argued that most researchers have wrongly concluded that cost overrun, escalation and growth are the same. Almost all publications in this area acknowledged that the problem of rework still remains an inescapable issue and common occurrence for Governments internationally [34, 35, 36, 31, 37, 38, 39, 40, 41, 42]. Most studies have it that incongruous design information contributes to this menacing problem. What these researchers 
failed to do was to quantify in financial terms how design information affected reliability of progress and cost estimates of construction and engineering projects $[43,9,44,45]$. This article provided answers to the how question in order to fill that knowledge gap.

\section{Methodology}

\subsection{Selection of Project Sites}

The attention is on two road construction projects namely; Project 'A' (11.0km road construction project in Brong Ahafo Region of Ghana with a contract sum of GHф10,069,064.59 which was to be completed within 12 calendar months) and Project 'B' (16.2km road construction project in Upper East Region of Ghana with a contract sum of GHф17,160,755.81 which was to be completed within 24 calendar months). The names of the two projects were withheld for ethical reasons. However, they were all Ghana Highway Authority (GHA) supervised projects and financed by the Government of Ghana (GoG).

\subsection{Study Type and Design}

A case study research style was used. According to [46], the case study as a research strategy comprises an allencompassing method with the logic of design incorporating specific approaches to data collection and to data analysis. In this sense, the case study is not either a data collection tactic or merely a design feature alone but a comprehensive research strategy. Yin [47], stated that the case study research allows an investigation to retain the holistic and meaningful characteristics of real-life events-such as individual life cycles, organizational and managerial processes, neighborhood change, international relations, and the maturation of industries. As a summary definition, [47], described a research design as a plan that guides the investigator in the process of collecting, analyzing, and interpreting observations. It is a logical model of proof that allows the researcher to draw inferences concerning causal relations among the variables under investigation. The research design correspondingly defines the domain of generalizability. That is, whether of the obtained interpretations can be generalized to a larger population or to different situations [47].

In collecting the data, literature review, a case study and personal observations were used to investigate different aspects of the research problem. In analyzing the data the authors reviewed topics related to background of design management in construction, quality of design information, information flow in design management, design information in road construction, time delays and cost overruns due to design information, consideration of project time and cost and dimensions of project success. A case study was also conducted. The tools used for the case study were semi-structured interviews, and a content analysis of design documents of the two road construction projects under study to show the extent to which design information on these projects affected the progress of construction.

\subsection{Study Area}

The research was conducted in the Brong Ahafo and the Upper East Regions, Ghana. Authors wanted projects situated in different geographical regions and with different GHA personnel handling the projects, hence, the choice of the two Regions. Again, case study research requires detailed review of information available. There is always an added advantage for "action base" kind of case study where the researcher is part of the activities under study. Therefore, one of the Authors became part of the projects team under consideration and that provided the opportunity to obtain the necessary information. Considering the nature of research, the consent of the key players in the projects was sort in order to obtain the desired information. Besides, the selected projects were at various levels of completion where adequate information could be obtained.

\subsection{Data Collection Tools}

Primary and secondary data were collected in the study. The primary data was obtained using semi-structured interviews. Major players in the road construction industry were interviewed on effects of design information in the progress of road construction. The interview was conducted to elicit information on the following:

1) Were there designs in place before signing the contract of the two road projects?

2) How accurate and comprehensive was the design information of the two road projects?

3) The level of understanding of design information among the consultants and the contractors.

4) The effects of the design information on the progress of construction on the two road projects.

Secondary data was obtained through the review of relevant literature and detailed content review of the design information on the two road projects.

\subsection{Methods Used to Analysis Data}

Explanatory and descriptive methods were used to analyze the data as explained by [46]. Yin [46] indicated that, there may be exploratory case studies, descriptive case studies, or explanatory case studies. Also, case studies are the preferred strategy when "how" or "why" questions are being posed, when the investigator has little control over events, and when the focus is on a contemporary phenomenon within some real-life context. Such "explanatory" case studies also can be complemented by two other types - "exploratory" and "descriptive" case studies [48].

In analyzing the data, the focus was to answer the following questions that were confronting the two road projects under study:

1) How come that the contact period of project ' $A$ ' exceeded more the $100 \%$ ?

2) Why is it that the cost of project ' $A$ ' increased by more than $36 \%$ of the initial contract sum?

3) Why the several changes in the design and construction of project ' $\mathrm{B}$ '?

4) What have been the effects of the several changes in project ' $\mathrm{B}$ ' on the contract execution? 
Following [48] concept of conducting case study analysis, a general analytic strategy of relying on theoretical propositions, case descriptions, and content explanations of the design information available in the two road projects were used.

\section{Results and Discussion}

\subsection{The Source and Flow of Design Information in Road Construction}

The sources and flow of design information as was established by the Authors in this research are summarized in Fig. 1.

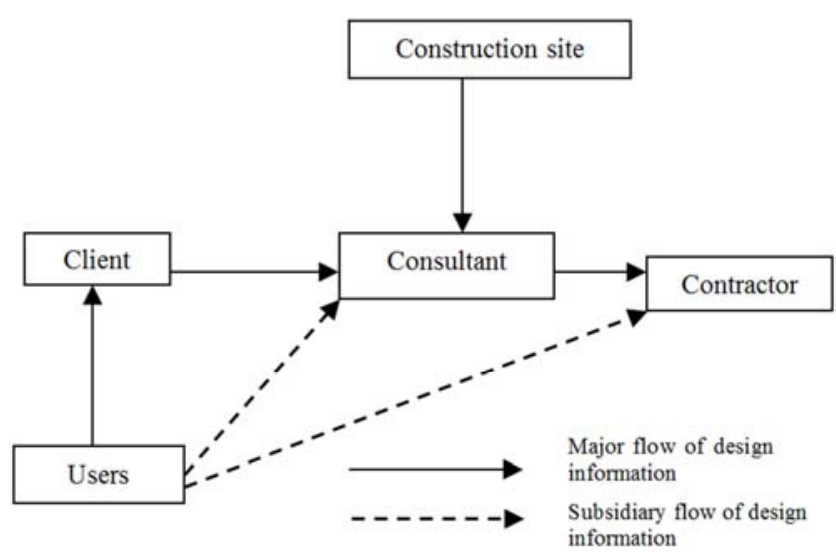

Figure 1. Sources and flow of design information in road construction.

The construction life cycle involves the six stages as noted by [49]: Planning and programming, design, construction, project closeout or commissioning, operations and maintenance, and disposal. Fallon and Palmer [49] discussed the importance of information flow throughout the stages in the project life cycle and called for effective collaboration among the clients, designers, contractors and the end users [49].

The Users (local residents or users of the road facility) present their case about the nature of their road and how it is affecting the economic activities of the area to the Government (Client). This information normally reaches the Government through the Chiefs, Opinion Leaders, Assembly Members and Members of Parliaments (MPs) to the Government reps such as the Metropolitan/Municipal/District Chief Executives, Regional Ministers and Sector Ministers.

The Client (in this case the Government), serves as a source of design information to the consultants where they provide what is known as the "Client Brief". The Government declares its intentions to the consultants (GHA, DFR - Department of Feeder Roads or DUR - Department of Urban Roads) as to the kind of road it required (asphalt, surface dressing or gravelling) based on the funding available. However, the institutions responsible for the road networks in Ghana have a clear definition of road network each agency covers. These institutions have the responsibility to examine the roads within their jurisdiction and present a comprehensive plan to the Government as to how it interns to develop or maintain such roads as well as the rough estimates. This information provides the Government with a clear picture of the problems in the road networks across the entire nation and therefore, incorporates some of the projects in its annual budget based on its priority areas and the funding it has been able to mobilize. The Ministry of Roads and Highways (MRH), after the Government has taking the decision to construct or rehabilitate such roads, writes to Chief Executive concern (thus GHA, DFR or DUR) to take the necessary steps to select suitable contractor for the project.

The GHA, DFR or DUR, being the consultants in coming out with the design of the road, visit the construction site and take the data of the site conditions which become the information in which they design the road against. The consultants prepares the design with specifications and submits same to the contractor who is the final recipient of the information for onward execution of the works. However, these state institutions may appoint a private consultant to undertake the designs and subsequently supervise the works on their behalf. Apart from these major sources and flow of design information, the Users of the road facility sometimes provide subsidiary information such as the economic activities of the area, traffic condition of the area etc. to the consultants or to the contractor which go a long way to ensure a perfect design and construction of the project.

\subsection{Findings from Project ' $A$ '}

The contract was awarded on the 8th June, 2011. The project commenced on the 1st August, 2011 and was supposed to be completed on the 1st August, 2012. The project involved $9.2 \mathrm{~km}$ road section and another $1.8 \mathrm{~km}$ road section in the contract. It was identified that the contractors were only given Bill of Quantities (BoQ) without the detailed design drawings to price and to estimate the period within which they could complete the projects. Therefore, the period of 12 calendar months which the contractor proposed to complete the project was based on the quantities of items provided in the BoQ. However, when the design drawings of the project were given to the contractor after the award of the contract, it was identified that there were several disparities between design details and BoQ.

On the $9.2 \mathrm{~km}$ stretch of the project, the major item on that stretch of the project was excavation through a rocky mountain of length $1.15 \mathrm{~km}$. The quantity of rock excavation in the BoQ was $22,000 \mathrm{~m}^{3}$. However, the quantity increased to $53,294 \mathrm{~m}^{3}$ after following the design levels to excavate the rock. Again, filling to embankment in the BoQ was $62,472 \mathrm{~m}^{3}$ which increased to $93,946 \mathrm{~m}^{3}$. Almost all the other items in the BoQ increased in a similar pattern as shown in Table 1.

Also, the design drawing indicates a road pavement width of $8 \mathrm{~m}$ along the stretch of $\mathrm{km} 0+000$ to $\mathrm{km} 7+450$ and $10 \mathrm{~m}$ within the stretch of $\mathrm{km} 7+450$ to $\mathrm{km} 9+000$. This meant that, the total quantity of subbase or base should have been $75,100 \mathrm{~m}^{2}$. However, the quantity of base in the BoQ was $73,600 \mathrm{~m}^{2}$, meaning, the estimator assumed the road width of $8 \mathrm{~m}$ for the entire $9.2 \mathrm{~km}$ road. It could therefore be concluded that the BoQ was prepared based on assumptions but not from the design. It is clear from Table 1 that, the average percentage increase in quantities of items in the $9.2 \mathrm{~km}$ section of project was $168.79 \%$. This partly accounted for the 
time delay and cost overrun of the project. These percentage increases are graphical shown in Fig. 2.

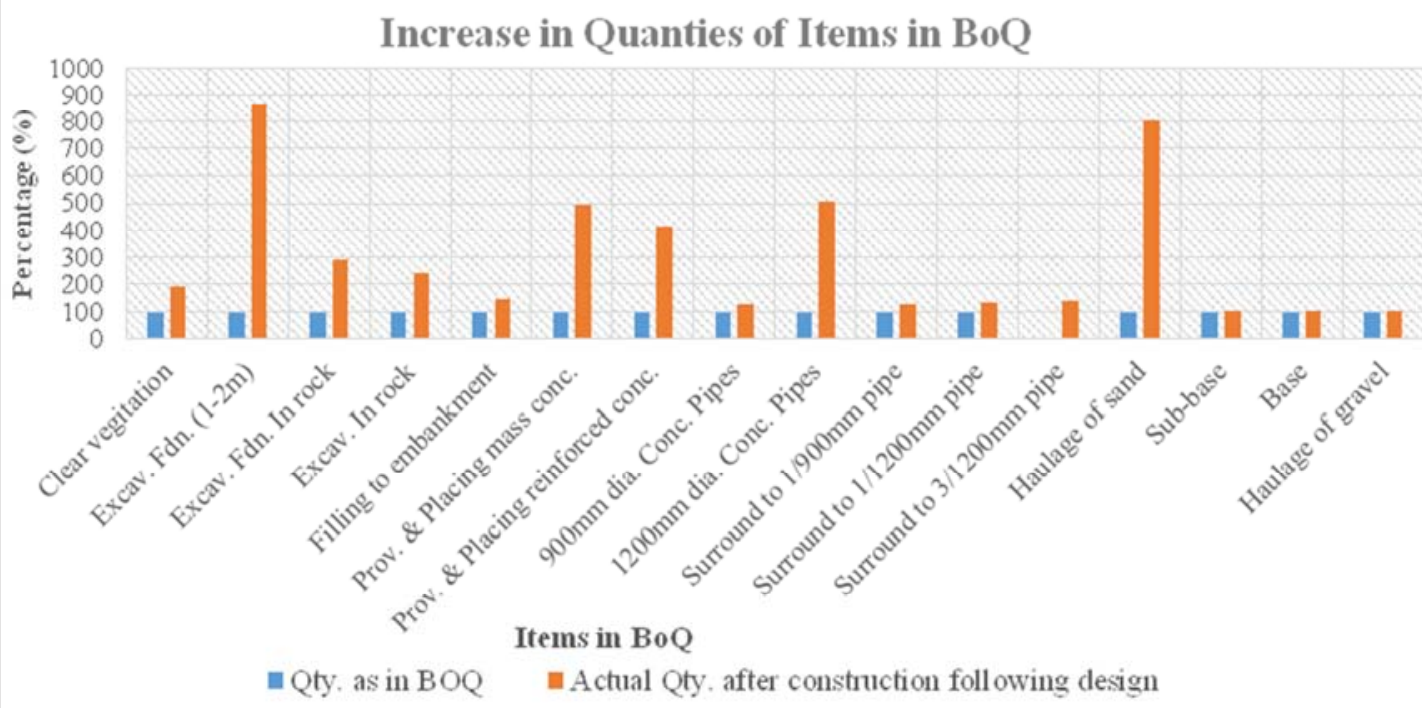

Figure 2. Disparities in BoQ and actual quantities constructed in project ' $A$ '.

Another problem identified was that, even when the design drawings were made available to the contractor, its content was not representative enough with respect to the situations on the ground. For instance, a provision of 13 No. new pipes culverts at various locations were to be provided as per the design. However, 15 No. culverts had to be constructed during construction stage. The sizes and lengths of some of the culverts had to be varied because the ones on the design could not support the flow of water in those locations. This confirms the point that enough site investigation was not conducted before coming out with the design. The disparities of the culvert provision are shown in Table 2.

Table 1. Disparities in design and BoQ quantities on $9.2 \mathrm{~km}$ in project ' $A$ '.

\begin{tabular}{|c|c|c|c|c|}
\hline Item & Description & $\begin{array}{l}\text { Quantity as } \\
\text { Provided in BoQ. }\end{array}$ & $\begin{array}{l}\text { Actual Quantity } \\
\text { Constructed After } \\
\text { Design }\end{array}$ & $\begin{array}{l}\text { Percent } \\
\text { Increase }\end{array}$ \\
\hline D 100 & Clear savannah vegetation including trees up to $100 \mathrm{~mm}$ girth. & $7 \mathrm{Ha}$ & $13.21 \mathrm{Ha}$ & $88.71 \%$ \\
\hline D 220 & Fell \& remove trees girth $(1.0-2.0 \mathrm{~m})$ & $150 \mathrm{Nr}$ & $265 \mathrm{Nr}$ & $76.67 \%$ \\
\hline D 230 & Fell \& remove trees girth $(2.0-3.0 \mathrm{~m})$ & $60 \mathrm{Nr}$ & $78 \mathrm{Nr}$ & $30.00 \%$ \\
\hline D 240 & Fell \& remove trees girth $(3.0-5.0 \mathrm{~m})$ & $24 \mathrm{Nr}$ & $55 \mathrm{Nr}$ & $129.17 \%$ \\
\hline D521.1 & Demolish existing plain concrete structure and remove from site. & $34 \mathrm{~m}^{3}$ & $63 \mathrm{~m}^{3}$ & $85.29 \%$ \\
\hline D521.2 & Demolish existing reinforced concrete structure. & $12 \mathrm{~m}^{3}$ & $30 \mathrm{~m}^{3}$ & $150.00 \%$ \\
\hline E 324 & Excavate for foundation in material other than rock depth $(1-2 \mathrm{~m})$. & $120 \mathrm{~m}^{3}$ & $1,037 \mathrm{~m}^{3}$ & $764.17 \%$ \\
\hline E 334 & Excavate for foundation in rock depth $(1.0-2.0 \mathrm{~m})$. & $90 \mathrm{~m}^{3}$ & $262 \mathrm{~m}^{3}$ & $191.11 \%$ \\
\hline E333.1 & Excavate for foundation in fused laterite. & 0 & $180 \mathrm{~m}^{3}$ & $180.00 \%$ \\
\hline E 533 & Excavate in rock. & $22,000 \mathrm{~m}^{3}$ & $53,294 \mathrm{~m}^{3}$ & $142.24 \%$ \\
\hline E 624 & Place and compact approved excavated fill materials in embankment. & $62,472 \mathrm{~m}^{3}$ & $92,472 \mathrm{~m}^{3}$ & $48.02 \%$ \\
\hline F 522 & Place mass concrete in bases footings \& ground slabs. & $25 \mathrm{~m}^{3}$ & $142 \mathrm{~m}^{3}$ & $468.00 \%$ \\
\hline F 542 & Place concrete in walls. & $17 \mathrm{~m}^{3}$ & $24 \mathrm{~m}^{3}$ & $41.18 \%$ \\
\hline F 642 & Place reinforced concrete in wall. & $18 \mathrm{~m}^{3}$ & $75 \mathrm{~m}^{3}$ & $316.67 \%$ \\
\hline G 253 & Fair formwork to curved surfaces. & $377 \mathrm{~m}^{2}$ & $712 \mathrm{~m}^{2}$ & $88.86 \%$ \\
\hline I 242 & Provide, lay \& joint $900 \mathrm{~mm}$ diameter pipe etc. & $132 \mathrm{~m}$ & $169 \mathrm{~m}$ & $28.03 \%$ \\
\hline I 253 & Provide, lay $\&$ joint $1200 \mathrm{~mm}$ diameter pipe etc. & $32 \mathrm{~m}$ & $163 \mathrm{~m}$ & $409.38 \%$ \\
\hline L544.1 & Mass concrete $25 / 20$ surround to $1 / 900 \mathrm{~mm}$ diameter precast concrete pipe etc. & $132 \mathrm{~m}$ & $169 \mathrm{~m}$ & $28.03 \%$ \\
\hline L545.1 & Mass concrete $25 / 20$ surround to $1 / 1200 \mathrm{~mm}$ diameter precast concrete pipe etc. & $32 \mathrm{~m}$ & $43 \mathrm{~m}$ & $34.38 \%$ \\
\hline L545.3 & Mass concrete $25 / 20$ surround to $3 / 1200 \mathrm{~mm}$ diameter precast concrete pipe etc. & 0 & $40 \mathrm{~m}$ & $40.00 \%$ \\
\hline L590.1 & Haulage of sand in excess of $1 \mathrm{~km}$ for items L543, L545 etc. & $1,277 \mathrm{~m}^{3} \mathrm{~km}$ & $10,253 \mathrm{~m}^{3} \mathrm{~km}$ & $702.90 \%$ \\
\hline R 115 & $\begin{array}{l}\text { Provide, lay and compact approved natural gravel sub-base material } 150 \mathrm{~mm} \text { thick } \\
\text { including } 1 \mathrm{~km} \text { haul. }\end{array}$ & $73,600 \mathrm{~m}^{2}$ & $75,100 \mathrm{~m}^{2}$ & $2.04 \%$ \\
\hline R 127 & Ditto natural gravel base $150 \mathrm{~mm}$ thick ditto. & $73,600 \mathrm{~m}^{2}$ & $75,100 \mathrm{~m}^{2}$ & $2.04 \%$ \\
\hline R190.1 & Haulage of natural gravel material in excess of $1 \mathrm{~km}$ for Items R155 \& R127. & $220,800 \mathrm{~m}^{3} \mathrm{~km}$ & $229,632 \mathrm{~m}^{3} \mathrm{~km}$ & $4.00 \%$ \\
\hline
\end{tabular}

Table 2. Culverts disparities on project ' $A$ '.

\begin{tabular}{lllll}
\hline Location $(\mathbf{k m})$ & Culvert as on design & Design length $(\mathbf{m})$ & Culvert finally constructed & Final length constructed $(\mathbf{m})$ \\
\hline $0+253$ & $1 / 0.9 \mathrm{~m} \varnothing$ pipe culvert & 12 & $1 / 0.9 \mathrm{~m} \varnothing$ pipe culvert & 12 \\
$0+300$ & $1 / 0.9 \mathrm{~m} \varnothing$ pipe culvert & 12 & $1 / 0.9 \mathrm{~m} \varnothing$ pipe culvert & 12 \\
$0+990$ & $2 / 1.2 \mathrm{~m} \varnothing$ pipe culvert & 12 & $3 / 1.2 \mathrm{~m} \varnothing$ pipe culvert & 45 \\
$1+000$ & $2 / 1.2 \mathrm{~m} \varnothing$ pipe culvert & 12 & - & - \\
$1+675$ & $1 / 1.2 \mathrm{~m} \varnothing$ pipe culvert & 20 & $1 / 1.2 \mathrm{~m} \varnothing$ pipe culvert & 15 \\
\hline
\end{tabular}




\begin{tabular}{|c|c|c|c|c|}
\hline Location (km) & Culvert as on design & Design length (m) & Culvert finally constructed & Final length constructed (m) \\
\hline $1+740$ & - & - & $1 / 0.9 \mathrm{~m} \varnothing$ pipe culvert & 15 \\
\hline $1+875$ & $1 / 1.2 \mathrm{~m} \emptyset$ pipe culvert & 12 & $1 / 1.2 \mathrm{~m} \varnothing$ pipe culvert & 15 \\
\hline $2+000$ & $1 / 1.2 \mathrm{~m} \emptyset$ pipe culvert & 12 & $2 / 1.2 \mathrm{~m} \emptyset$ pipe culvert & 18 \\
\hline $2+350$ & $1 / 1.2 \mathrm{~m} \emptyset$ pipe culvert & 12 & $2 / 1.2 \mathrm{~m} \emptyset$ pipe culvert & 15 \\
\hline $2+450$ & - & & $1 / 0.9 \mathrm{~m} \varnothing$ pipe culvert & 15 \\
\hline $3+032$ & $1 / 0.9 \mathrm{~m} \varnothing$ pipe culvert & 12 & $1 / 0.9 \mathrm{~m} \emptyset$ pipe culvert & 13 \\
\hline $3+132$ & $1 / 0.9 \mathrm{~m} \emptyset$ pipe culvert & 12 & $1 / 0.9 \mathrm{~m} \emptyset$ pipe culvert & 13 \\
\hline $3+504$ & $1 / 0.9 \mathrm{~m} \varnothing$ pipe culvert & 12 & 1/0.9m Ø pipe culvert & 12 \\
\hline $5+532$ & $1 / 0.9 \mathrm{~m} \varnothing$ pipe culvert & 12 & 1/0.9m Ø pipe culvert & 13 \\
\hline $6+240$ & - & - & $1 / 0.9 \mathrm{~m} \emptyset$ pipe culvert & 13 \\
\hline $7+450$ & $1 / 0.9 \mathrm{~m} \emptyset$ pipe culvert & 12 & $1 / 0.9 \mathrm{~m} \emptyset$ pipe culvert & 12 \\
\hline
\end{tabular}

These culvert disparities caused the total cost of constructing the culverts to rise from GHф641,454.50 to $\mathrm{GH} \notin 997,375.45$, an increase of $55.49 \%$ of the estimated cost in BoQ. On the $1.8 \mathrm{~km}$ stretch, the information on the line diagram shows a road width of $10 \mathrm{~m}$. This means that the total quantity of subbase or base materials should have been $18,000 \mathrm{~m}^{2}$. However, the quantity of subbase or base in the BoQ was $12,600 \mathrm{~m}^{2}$, resulting in a difference of $5,400 \mathrm{~m}^{2}$. This had huge financial implications on the project. For instance, the cost on the $5,400 \mathrm{~m}^{2}$ difference alone is as analyzed in Table 3.

Table 3. Cost grow in BoQ of the base and subbase material in project 'A'.

\begin{tabular}{llll}
\hline $\begin{array}{l}\text { Pavement } \\
\text { Layer/Material }\end{array}$ & Quantity & Rate (GHe) & $\begin{array}{l}\text { Amount } \\
\text { (GHe) }\end{array}$ \\
\hline Subbase & $5,400 \mathrm{~m}^{2}$ & 2.60 & $14,040.00$ \\
Base & $5,400 \mathrm{~m}^{2}$ & 2.70 & $14,580.00$ \\
Haulage & $3,240 \mathrm{~m}^{3} \mathrm{~km}$ & 1.20 & $3,888.00$ \\
Kerosene & $1,210 \mathrm{Litres}$ & 3.80 & $4,598.00$ \\
Primer seal bitumen & $6,350 \mathrm{Litres}$ & 4.20 & $26,670.00$ \\
10mm chippings & $45 \mathrm{~m}^{3}$ & 259.00 & $11,655.00$ \\
Bitumen for seal & 7,560 Litres & 4.20 & $31,752.00$ \\
14mm chippings & $60 \mathrm{~m}^{3}$ & 259.00 & $15,540.00$ \\
Total & & & $122,723.00$ \\
\hline
\end{tabular}

Again, there was no culvert along the stretch of the $1.8 \mathrm{~km}$ section in the design. However, two $1 / 0.9 \mathrm{~m}$ diameter pipe culverts had to be introduced at a total cost of GH $ф 102,406.10$ to solve severe flooding problem in some areas. Thus, confirming the poor site investigation conducted before the design. This did not only increase the cost of the project, but also slowed down the work. When the Maintenance Engineer and the Regional Quantity Surveyor of GHA responsible for the project were interviewed as to why these disparities occurred, their response was that there was a rush in preparing the tender documents which the BoQ forms part in order to get a contractor to work on the road as quickly as possible. This was because the road had completely been cut-off making it difficult for people in that area to transport farm produce to the market center. There was therefore the need to quickly come out with approximate quantities of the items while the detailed design was being prepared. When asked whether that was the normal practice, the answer was negative. However, they admitted that sometimes emergency situations required rapid measures to salvage the situation which meant that timing for the award of the contract could be of great essence to get a contractor to solve certain problems initially whiles the design drawings are being prepared.

Another problem which was identified on project 'A' was the fact that the line diagrams for the drains were not detailed enough. It therefore required the experience of the contractor on similar works to execute the drains. The line diagrams showed sketch of the shapes of the drains without any dimensions or schedules to guide the contractor. It is clear that the design information on project ' $A$ ' have affected the project significantly in terms of progress and cost. The project which was supposed to be completed in 1st August, 2012, was $88 \%$ complete as at the end of December, 2013; an increase of 17 calendar months representing $141.67 \%$ of the contract duration. Again, the contract sum of $\mathrm{GH} \phi$ $10,069,064.59$ has been increased to GHф $13,739,824.47$ (thus, an increase of $36.46 \%$ of the contract sum). Notwithstanding the challenges on the design as discussed above, the design alignments followed the topography of the area. The final road as executed by the contractor was very beautiful. However, the construction of the road was still in progress and therefore the durability of the road could not be confirmed.

In as much as has been established that design information had contributed significantly to the delay and increase cost of the project, other factors such as non-payment of the contractor's certificate on time and sometimes the breakdown of the contractor's equipment on the project also had effect on the delay. The contractor suspended work on 6th May, 2013 and wrote to GHA that they were suspending work because they were not getting payment for works already executed and this was certified by the consultant. This suspension of work lasted up to 31st August, 2013 where the contractor resumed work. It meant that the four months suspension of work period could not be attributed to design implications.

\subsection{Findings from Project ' $B$ '}

The contract was awarded on 6th March, 2012 and was supposed to be completed on 5th March, 2014. The contract involved three projects which were put together as one contract. It includes a $3.4 \mathrm{~km}$ road, $7.6 \mathrm{~km}$ road and $5.2 \mathrm{~km}$ road. On the first $3.4 \mathrm{~km}$ stretch, there were proposed design drawings but were not made available to the contractor during tendering. Therefore, the contractor's assessments and programs were based on the information in the BoQ. However, the design drawings which were provided to the contractor after the award of the contract, happened to be an old road design for the stretch which was prepared over 10 years ago. It was identified that not much due diligence was made to ascertain whether the designs were still feasible before asking the contractor to go ahead to use information 
on the designs to execute the work. Therefore, there were several problems at the construction stage. One of the problems was that there were new encroaching structures close to the road which needed to be demolished. However, this had not been catered for in the design. No compensation estimates or costs have been factored into the BoQ. The valuation of the cost of structures involved was estimated as GH $\varnothing 300,000.00$. Therefore, works on such portions of the road had been suspended to-date whiles Government look for funds to pay the compensation before work could resume on that portion of the road.

Another problem which was identified on the $3.4 \mathrm{~km}$ stretch was that, there was an existing U-drain on that stretch of the project which the contractor was asked not to demolish because the consultants thought the drains could still function. However, it was identified that the drain structure was too narrow and for that matter, longitudinal drains always overflow whenever it rained causing damage to properties of people who lived close to the road. The consultants were on the process of raising a variation order (VO) at the time of this study, to cater for the demolition of the old U-drains and the construction of new drains which could address the flooding problem in that area.

On the other $7.6 \mathrm{~km}$ stretch of the project, the contractor was given a design after the award of the contract. However, the following defects were identified during the construction stage of the project as a result of poor feasibility studies and poor pre-design assessment:

- Wrong levels detailing for the drains. The invert levels at certain portions of the drains along the stretch of the road as indicated on the design were wrong leading to the top levels of the drains being far higher than the road pavement levels. Therefore, water was not able to flow through the drains after construction causing flooding in that area. The contractor was then asked to demolish those sections of the drains, reconstruct new ones, all to the cost of the client because it was not the fault of the contractor.

- That stretch of the project was formally under DFR which was then converted to GHA under this contract. Therefore, the existing culverts were all the U-shaped culverts as had always been for feeder roads. It was identified that the consultants did not conduct enough test to ascertain the strength of the existing 12 No. culverts along the stretch before instructing the contractor to extend those culverts from $12 \mathrm{~m}$ to $15 \mathrm{~m}$ to meet the width of the road.

- Unfortunately, after the contractor had extended those culverts, filled the approaches with gravels and work on the project had progressed up to the subbase level, 2 of the culverts failed. Checks on the other 10 culverts revealed that they were on the verge of failing. The contractor was then instructed to demolish all these culverts and replace with new $900 \mathrm{~mm}$ diameter pipe culverts. This did not only slow down the progress of works, it had brought huge cost burden to the client. The contractor was paid for extending the existing Ushaped culverts, paid for the demolition of all the failed culverts and also paid for the construction of the new culverts.
The total cost for the extension of the 12 No. U-shaped culverts from $12 \mathrm{~m}$ to $15 \mathrm{~m}$ each was $\mathrm{GH} \notin 306,912.40$ with a price adjustment fluctuation of $19.3 \%$ at that time. However, after the demolition all the U-shaped culverts, 8 No. $1 / 900 \mathrm{~mm}$ diameter pipe culverts were constructed which were enough to serve the same purpose. But the total cost for the demolition and the construction of the 8 new culverts amounted to $\mathrm{GH} \notin 153,366.60$. Unfortunately, the price adjustment fluctuation had increase to $30 \%$ at the time of reconstruction. This means that the Government could have saved about GHф153,545.80 cost if proper feasibility studies had been carried out and the problems factored into the design of the project.

On the last $5.2 \mathrm{~km}$ stretch of the project, it was established that there was no design during the signing of the contract on the 6th March, 2012. A private Architect was contracted to execute the design for that stretch. The Architect was only able to come out with the design in August, 2012 delaying the project for 5 months after the signing of the contract. Due to the absence of design, the Maintenance Engineer of GHA in the Region sited $15 \mathrm{~m}$ length of $900 \mathrm{~mm}$ diameter pipe culvert at a location to avoid imminent cut of the road from motorist as a result of erosion. The contractor finished the construction of the culvert before the arrival of the design at the total cost of $\mathrm{GH} \notin 33,150.60$. Regrettably, it was realized that the culvert had been sited at a wrong location upon following the design. Therefore, the culvert was demolished and a new one realigned and constructed to suit the design provision. Here again the contractor was paid for constructing the first culvert, the demolition and the reconstruction of the new culvert at a total cost of GH $₫ 42,576.60$. Also, not much feasibility studies were carried out. Therefore, it was observed that certain section of the road required the construction of culverts to be able to carry the surface water. However, only concrete side drains were provided thereby causing flooding in those portions of the road. In other words, the design drawings were not representative enough to the situation on the ground.

It was quite clear that the issue relating to design information as far as project ' $\mathrm{B}$ ' is concern had a significant effects on the progress and cost estimates of the construction. The information on the project indicates that the project which was supposed to be completed on 5th March, 2014, was only $60 \%$ complete as at 30 th November, 2013. Studies on the work programmed indicated that the project was $30 \%$ behind time. This alone has financial implications due to fluctuations which will be accrued within the period. Again, due to several changes, as had been explained above, the cost of the project had gone up by $26 \%$ as at the $60 \%$ physical completion reached so far.

The general challenge identified in the two road projects under this study was the low speed in taking decisions with regards to variations by the projects team. Sometimes, when the variations require additional funds outside the contract sum, the GHA at the Regional level had to seek approval from the GHA Head Office in Accra, who also intern seek approval from the Central Tender Board (CTB) before taking decision on it. This bureaucratic system turns to delay the project. Even when the variations are not likely to cause any increase in funding and does not require this bureaucratic 
procedure, the construction team (consultants and contractors) waste too much time in taking the final decision on the changes to be done. This is the more reason why there is the need to ensure quality design at the beginning of the project to avoid these unnecessary delays.

\subsection{Summary of Findings}

The research revealed the following facts about design information management in the road construction sector as practiced by the GHA, the Government institution responsible for the management of trunk roads in Ghana:

1) Some contracts were signed without project designs. The designs were prepared after the award of the contract. This pressured the designers to come out with the design drawings in order not to cause undue delay of the project. This also resulted in errors on the designs which were not detected and therefore carried to the construction stage before they were detected.

2) The contractors who tendered for projects without design details drew their schedules based on the available quantities in the BoQ. Therefore, any substantial increase in quantities disrupted the contactor's program and caused delay of the project.

3) Some BoQ were prepared at the time when design drawings were not ready. This lead to disparities in the design drawing information and the BoQ information.

4) Not much feasibility studies were conducted before coming out with road designs. This resulted in several changes in the construction stage thereby causing time delays and cost overruns of the project.

5) There were increased delays in taking decision on variations by the project team.

\section{Conclusions}

The pursuit of better design information is rooted in the assumption that it will lead to better design, planning, and execution of construction work. Better design and planning are requirement for better construction and product (fewer defects or fewer budget overruns or delays). Researchers were able to establish that design information on the two road projects affected the smooth progress of the works. The delays which bedeviled the two projects were mostly due to the design changes during construction which affected the quantities of items in the contract. The increases in cost of the projects were also as a result of the changes in the design and poor management of the projects by GHA. The capital intensive nature of road construction demands that proper design administration is always carried out in order to minimize the time delays and cost overruns which normally characterize road construction works especially the Government of Ghana (GoG) funded ones. For instance, the project's 'A' and ' $B$ ' were $142 \%$ and $30 \%$ respectively behind time. The cost had also gone up by $37 \%$ and $26 \%$ for projects " $A$ " and "B" respectively. It therefore requires the necessary collaboration and inputs by the entire stakeholders in the road sector to achieve the desired results of value maximization and waste minimization.

The following recommendations have been made to avert the problems arising out of the flaws in design information:

1) The design plays the central role in the success of every road construction project. Therefore the GHA, DFR and DUR which have been tasked with the responsibility to prepare road designs must ensure that proper feasibility studies are conducted so that critical site conditions are factored into the design in order to eliminate the defects that normally come with the design.

2) GHA, DFR and DUR must ensure that the detailed design drawings are ready before tendering and drawings incorporated in the tender documents so that the contractors who wish to tender for the project could make an informed decision based on the detailed information available to them.

3) There must be a good collaboration between the Engineers designing the roads and the Quantity Surveyors who prepares the BoQ in order to avoid disparities in the design drawings and the BoQ. This will help to keep the project in check against cost overruns, time delays and reworks.

4) The consultants on road projects must test the strength and functioning of existing structures (drains, culverts, slabs etc.) before issuing instructions to contractors to demolish, extend or maintain them to help reduce waste.

5) There must be a system in place to deal with variations quickly enough to avoid disruption of the contract period.

\section{Acknowledgments}

The Authors would like to acknowledge the supportive roles of Ghana Highway Authority staff in the Brong Ahafo and Upper East Regions, and our BTech student Mr. Seidu Tamon Basubinin for facilitating the data collection process.

\section{References}

[1] M. Sarfo, "The Effect of Project Management Practices on Bulding Project Performance: The Case of Three Organizations," Kumasi, Ghana, 2007.

[2] C. Hendrickson and T. Au, Project Management for Construction: fundamental for owners, engineers, architects and builders, Englewood Cliffs, N. J.: Prentice Hall, 1998, p. 537.

[3] N. Chileshe and P. D. Berko, "Causes of project cost overruns within the Ghanaian road construction sector," in Proceedings of 5th Built Environment Conference held from 18-20 July 2010, Durban, South Africa, 2010.

[4] J. L. Carpenter, "An Analysis of a Guaranteed Achievement Program to Achieve Specific Educational Objectives, or Performance Contracting, Chicago Style," in Paper presented at American Educational Research Association Meeting held on 25 February to 1st March 1973, New Orleans, Louisiana, 1973.

[5] P. A. Tyrrell, M. L. Lake and W. A. Parsons, An Investigation of the Extra Costs Arising on Highway Contracts, Wokingham, Berkshire UK: Transport and Road Research Laboratory (TRRL), 1983. 
[6] B. Flyvbjerg, M. K. S. Holm and S. L. Buhl, "How common and how large are cost overruns in transport infrastructure projects?," Transport Reviews, vol. 23, no. 1, p. 71-88, 2003.

[7] P. Berko, "Project Cost Overrun in the Road Construction Industry in Ghana," Sheffield, U.K., 2007.

[8] V. Alexeeva, G. Padam and C. Queiro, "Monitoring Road Works Contracts and Unit Costs for Enhanced Governance in Sub-Saharan Africa," World Bank, Washington, D. C., 2008.

[9] O. B. Berard, F. Vestergaard and J. Karlshoej, "Building Information Modeling for Managing Design and Construction: Assessing Design Information Quality," Technical University of Demark. (BYG Rapport), Kgs. Lyngby, 2012.

[10] L. Koskela, Foundations of Concurrent Engineering. Concurrent Engineering in Construction Projects, 1 ed., London, UK: Taylor \& Francis,, 2007, p. 12-29.

[11] H. Chris and T. Au, Project Management for Construction: fundamental for owners, engineers, architects and builders, Englewood Cliffs: Prentice Hall, 2000.

[12] R. Best and G. Valence, Building in Value - pre-design issues, London, UK: Arnold Publishers, 1999.

[13] N. D. Long, S. Ogunlana, T. Quang and K. C. Lam, "Large construction projects in developing countries: a case study from Vietnam," International Journal of project management, vol. 22, no. 7, pp. 553-561, 2004.

[14] B. Flyvbjerg, "Policy and Planning for large Infrastructure Projects: Problems, Causes, Cures," 2005.

[15] P. E. Love, D. J. Edwards, H. Watson and P. R. Davis, "Rework in civil engineering infrastructure projects: determination of cost predictors," Journal of Construction, Engineering and Management, vol. 136, no. 3, pp. 271-398, 2010 .

[16] B. Flyvbjerg, M. Garbuio and D. Lovallo, "Delusion and deception in large infrastructure projects: two models for explaining and preventing executive disaster," California Management Review, vol. 51, no. 2, pp. 170-193, 2009.

[17] A. Iimi, "Infrastructure Procurement and Ex Post Cost Adjustments - Evidence from ODA Financed Road Procurement in Africa held from 14th to 15th January, 2009," in The World Bank International Conference on Infrastructure Economics and Development, Toulouse, France, 2009.

[18] D. W. M. Chan and M. M. Kumaraswamy, "Compressing construction durations: lessons learned from Hong Kong building projects," International Journal of Project Management, vol. 20, no. 1, pp. 23-35, 2002.

[19] J. A. Kuprenas, "Project management actions to improve design phase cost performance," Journal of Management in Engineering, vol. 19, no. 1, pp. 25-32, 2003.

[20] D. W. Chan and M. M. Kumaraswamy, "An evaluation of construction time performance in the building industry," Building and Environment Journal, vol. 31, no. 6, pp. 569578, 1996.

[21] A. A. Okuwoga, "Cost, time performance of public sector housing projects in Nigeria," Habital Intl., vol. 22, no. 4, pp. 389-395, 1998

[22] Performance Audit Report on Road Works, "The Ministry of Infrastructure Development and TANROADS Performance in Controlling Road Construction Time, Cost and Quality," A Report of the Controller and Auditor General of the United Republic of Tanzania, Tanzania, 2010.
[23] G. Creedy, "Risk Factors Leading to Cost Overrun in Highway Projects," in Proceeding of Queenland University of Technology Research Week International Conference, Brisbane, Australia, 2005.

[24] R. Morledge, D. Bassett and A. Sharif, "Client Time Expectation and Construction Industry Performance, Nottingham Trent University," in COBRA '96, Nottingham, 1996.

[25] D. W. Chan and M. M. Kumaraswamy, "A study of the factors affecting construction durations in Hong Kong," Construction Management and Economics, vol. 13, no. 4, p. 319-333, 1995.

[26] S. C. Ward, B. Curtis and C. B. Chapman, "Objectives and performance in construction projects," Construction Management and Economics, vol. 9, no. 4, pp. 343-353, 1991.

[27] A. A. Bubashit and S. A. Almohawis, "Evaluating the general conditions of a construction contract," International Journal of Project Management, vol. 12, no. 3, pp. 133-135, 1994.

[28] A. Sadeh, D. Dvir and A. Shenhar, "The role of contract type in success of $\mathrm{R} \& \mathrm{D}$ defence projects under increasing uncertainty," Project Management Journal, vol. 31, no. 3, pp. 14-21, 2000.

[29] A. P. C. Chan and D. W. M. Chan, "Developing a benchmark model for project construction time performance in Hong Kong," Building and Environment, vol. 39, no. 3, pp. 339-349, 2004 .

[30] A. J. Shenhar, O. Levy and D. Dvir, "Mapping the dimensions of project success," Project Management Journal, vol. 8, no. 2, pp. 5-13, 1997.

[31] M. Hannah and G. Srinivasan, "A study on the resource factors influencing the scheduling performance in construction industries," International Journal of Engineering Research \& Technology (IJERT), vol. 3, no. 4, pp. 803-805, 2014.

[32] J. O. Olaniran, E. D. P. Love, D. Edwards, A. O. Olatunji and J. Matthews, "Cost overruns in hydrocarbon megaprojects: a critical review and implications for research," Project Management Journal, vol. 46, no. 6, p. 126-138, 2015.

[33] P. E. D. Love, J. E. David and J. Smith, "Rework causation: emergent theoretical insights and implications for research," Journal of Construction Engineering and Management, vol. 142, no. 6, p. 04016010, 2016.

[34] R. O. Asiedu and H. W. Alfen, "Understanding the underlying reasons behind time overruns of government building projects in Ghana," KSCE Journal of Civil Engineering, vol. 20, no. 6, p. 2103-2111.

[35] R. F. Aziz and A. A. Abdel-Hakam, "Exploring delay causes of road construction projects in Egypt," Alexandria Engineering Journal, vol. 55, no. 2, p. 1515-1539, 2016.

[36] P. González, V. González, K. Molenaar and F. Orozco, "Analysis of causes of delay and time performance in construction projects," Journal of Construction Engineering and Management, vol. 140, no. 1, pp. 1-9, 2014.

[37] M. Kadry, H. Osman and M. Georgy, "Causes of construction delays in countries with high geopolitical risks," Journal of Construction Engineering and Management, vol. 142, no. 10, p. 04016095,2016 .

[38] I. Mahamid, A. Bruland and N. Dmaidi, "Causes of delay in road construction projects," Journal of Management in Engineering, vol. 28, no. 3, pp. 300-310, 2012. 
[39] E. P. Love, D. D. Ahiaga-Dagbui and Z. Irani, "Cost overruns in transportation infrastructure projects: sowing the seeds for a probabilistic theory of causation," Transportation Research Part A: Policy and Practice, vol. 92, p. 184-194, 2016.

[40] T. M. R.-K. Akogbe, X. Feng and J. Zhou, "Importance and ranking evaluation of delay factors for development construction projects in Benin," KSCE Journal of Civil Engineering, vol. 17, no. 6, p. 1213-1222, 2013.

[41] Y. Li and R. B. T. Taylor, "Modeling the impact of design rework on transportation infrastructure construction project performance," Journal of Construction Engineering and Management, vol. 140, no. 9, p. 04014044, 2014.

[42] M. D. R. Mizanur, Y. L. Dai and D. H. Khanh, "Investigating main causes for schedule delay in construction projects in Bangladesh," KICEM Journal of Construction Engineering and Project Management, vol. 4, no. 3, 2014.

[43] H. Abdul-Rahman, C. Wang and H. B. J. Yap, "Impacts of design changes on construction project performance: Insights from a literature review," in 14th Management In Construction Researchs' Association (MiCRA 2015) Annual Conference and General Meeting held from November 12th- 13th at Kulliyyah of Architecture and Environmental Design (KAED), Gombak, Malaysia, 2015.

[44] M. Mohamad, M. Nekooie and A. Al-Harthy, "Design changes in residential reinforced concrete buildings: the causes, sources, impacts and preventive measures," Journal of Construction for Developing Countries, vol. 17, no. 2, p. 2344, 2012.

[45] B. H. J. Yap, H. Abdul-Rahman and C. Wang, "A conceptual framework for managing design changes in building construction," in MATEC Web of Conferences 66, 2016.

[46] R. K. Yin, Case Study Research: Design and Methods, 1 ed., vol. 4, London UK: SAGE Publications, 1981.

[47] R. K. Yin, Case Study Research: Design and Methods, 2 ed., vol. 5, London, UK: SAGE Publications, 1983.

[48] R. K. Yin, Case study research: design and methods, 4 ed., vol. 7, London, UK: SAGE Publications, 2003.

[49] K. K. Fallon and M. E. Palmer, General Building Information Guide: Principles, Methodology and Case Studies, NIST, U.S Department of Commerce, 2007. 